\title{
XPS and IR Spectroscopic Studies of Titanyl and Vanadyl Complexes with Etioporphyrin II
}

\author{
Tatyana A. Ageeva, ${ }^{a}$ Denis V. Golubev, ${ }^{\mathrm{b}}$ Anastasiya S. Gorshkova, ${ }^{\mathrm{b}, \mathrm{c}}$ \\ Andrey M. Ionov, ${ }^{d}$ Elena V. Kopylova, ${ }^{\mathrm{b}}$ Oskar I. Koifman, ${ }^{\mathrm{a}}$ Rais N. Mozhchil, ${ }^{\mathrm{d}}$

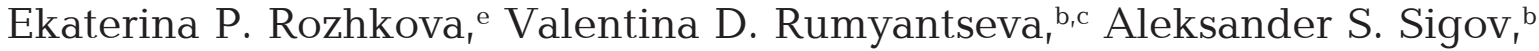 \\ and Valeriy V. Fomichev ${ }^{\mathrm{b}}$
}

\author{
avanovo State University of Chemistry and Technology, 153000 Ivanovo, Russia \\ ${ }^{\mathrm{b}}$ MIREA - Russian Technological University, 119571 Moscow, Russia \\ ${ }^{c}$ Kotel'nikov Institute of Radio Engineering and Electronics RAS, 141190 Fryazino, Russia \\ dinstitute of Solid State Physics RAS, 142432 Chernogolovka, Russia \\ ${ }^{\mathrm{e}}$ LLC NPF Fire Protection Engineering Laboratory, 606016 Dzerzhinsk, Russia \\ @Corresponding author E-mail: valeryfom@rambler.ru
}

\begin{abstract}
The study is devoted to search for organometallic complexes with considerable dipole moments suitable for the creation of new electret materials. The latter are formed by intercalation of organometallic molecules with a high dipole moment into a polymeric matrix. Titanyl and vanadyl complexes with etioporphyrin II were synthesized. The obtained compounds were identified with the use of electronic spectroscopy, NMR spectroscopy, mass spectrometry and liquid chromatography, and studied by vibrational spectroscopy and X-ray photoelectronic spectroscopy. Quantum chemical calculations for the optimization of the geometry of etioporphyrin II complexes with vanadyl and titanyl cations were performed. Their vibration spectra, dipole moments and distribution of charge and spin densities were calculated. Mulliken population analysis was carried out. It was shown that the "apix" bond between the metal in the vanadyl complex with etioporphyrin II is of more pronounced covalent nature. In contrast, in case of titanyl a structure with some redistribution of electron density onto the oxygen atom is implemented. This increases the polarity of the "apix" $\mathrm{Ti}-\mathrm{O}$ bond and the dipole moment of the titanyl macrocomplex in general. The calculated dipole moment of the titanyl complex is higher $(2.94 \mathrm{D})$ than that of the vanadyl complex $(2.32 \mathrm{D})$.
\end{abstract}

Keywords: Titanyl, vanadyl, etioporphyrin II, metal complexes, IR spectroscopy, X-ray photoelectron spectroscopy, dipole moment.

\section{РФЭС и ИК спектроскопическое исследование комплексов титанила и ванадила с этиопорфирином II}

\author{
T. А. Агеева, ${ }^{a}$ A. В. Голубев, ${ }^{\text {b }}$ А. С. Горшкова, ${ }_{1}^{\text {b, }}$ А. М. Ионов, ${ }^{\mathrm{d}}$ Е. В. Копылова, ${ }^{\mathrm{b}}$

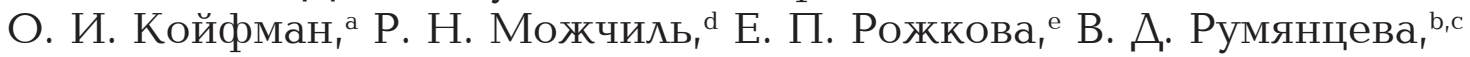 \\ А. С. Сигов, ${ }^{\text {b }}$ В. В. Фомичев ${ }^{\mathrm{b}}$
}

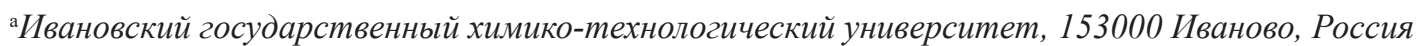

${ }^{\mathrm{b}}$ Российский технологический университет МИРЭА, 119571 Москва, Россия

${ }^{\mathrm{c}}$ Институт радиотехники и электроники им. В.А. Котельникова РАН, 141190 Фрязино, Россия

${ }^{\mathrm{d}}$ Институт физики твердого тела РАН, 142432 Черноголовка, Россия

'ООО НПФ «Лаборатория огнезащитыл», 606016 Дзержинск, Россия

@E-mail: valeryfom@rambler.ru
}

Настоящзее исследование направлено на поиски металлоорганических комплексов с существенными дипольными моментами, пригодных для создания новых электретных материалов. Последние формируются путем 
интеркалящии металлоорганических молекул с большим дипольным моментом в полимерную матрииу. Выполнен синтез комплексов титанила и ванадила с этиопорфирином II. Используя набор физико-химических методов (электронная спектроскопия, спектроскопия ЯМР, масс-спектрометрия, жидкостная хроматография), проведена идентификачия полученных соединений. Методами колебательной спектроскопии и рентгеновской фотоэлектронной спектроскопии выполнено исследование полученных комплексных соединений. Bыполнены квантово-химические расчеты оптимизаџии геометрии комплексов этиопорфирина II с катионами ванадила и титанила, расчет их колебательных спектров, дипольных моментов, также распределение зарядовой и спиновой плотности, анализ заселенностей по Малликену. Показано, что «апиксная» связь металл в ванадильном комплексе с этиопорфирином II имеет более выраженный ковалентный характер, в то время как для титанила реализуется структура с некоторым перераспределением электронной плотности на атом кислорода, что повышает полярность «апиксной» связи Ті-О и увеличивает дипольный момент макрокомплекса титанила в иелом. Рассчитанный дипольный момент комплекса титанила (2.94 D) превышает момент комплекса ванадила (2.32 D).

Ключевые слова: Титанил, ванадил, этиопорфирин II, металлокомплексы, ИК спектроскопия, рентгеновская фотоэлектронная спектроскопия, дипольный момент.

\section{Introduction}

In the previous study ${ }^{[1]}$ we have shown the possibility of creating a new design of an electret material. The idea consisted in the intercalation of organometallic macromolecules of bismuth(III) iodide complexes with porphyrins having high dipole moments ${ }^{[2,3]}$ into PVA upon polymerization in a constant electric field. The latter allows fixing the preset direction of dipole moment vectors in the material, while the use of the macroligand guarantees time stability of the surface potential preventing relaxation processes.

This work is aimed at searching new organometallic complexes with considerable dipole moments suitable for implementing the suggested electret material model. On the basis of literature data analysis, we suggested to consider titanyl or vanadyl complexes with porphyrins as such objects. The previous studies demonstrated that the maximum dipole moment can be obtained for compounds with etioporphyrin II.

With the use of vibrational spectroscopy and X-ray photoelectronic spectroscopy supported by quantum chemical calculations the bismuth iodide complex with this porphyrin was shown to have the highest dipole moment among all the compounds studied by us before. ${ }^{[1]}$ It is admissible to expect that the strong "apix" $\mathrm{M}-\mathrm{O}$ bonds in titanyl

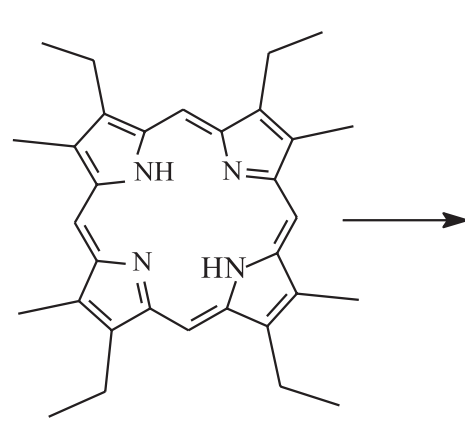

1.

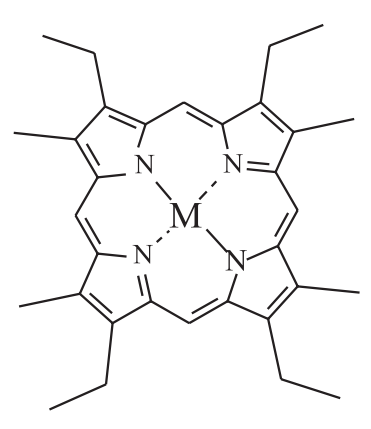

2. $\mathrm{a}: \mathrm{M}=\mathrm{VO}$ $\mathrm{b}: \mathrm{M}=\mathrm{TiO}$
Figure 1. Scheme of etioporphyrin II metal complexes. and vanadyl complexes directed normally to the ligand plane will provide a high contribution to the dipole moment of the macromolecule in general.

The synthesis of VO EP II (Figure 1) was described earlier. ${ }^{[4,5]} \mathrm{TiO}$ EP II was prepared by our group and characterized for the first time. The vibrational spectra of a number of EP II metal complexes were published several years ago, ${ }^{[6]}$ however, the assignment of vibration frequencies was limited to the high-frequency area. No analysis of vibrations of the porphyrin cycle atoms bonded to the transition element was carried out.

\section{Experimental}

\section{Synthesis}

Etioporphyrin II (1, EP II) was obtained by H. Fischer method $^{[7]}$ from 4,4'-dimethyl-3,3'-diethyl-5,5'-diethoxycarbonyldipyrromethane. VO EP II complex was synthesized by two methods: by refluxing EP II with vanadyl sulphate in $\mathrm{DMF}^{[8]}$ or with $\mathrm{VO}(\mathrm{IV})$ acetylacetonate prepared according to the method ${ }^{[9]}$ by refluxing in phenol. ${ }^{[10]}$ The reaction durations in both methods and also the final complex yields had the close values. Titanyl was inserted into the macrocycle with $\mathrm{TiO}(\mathrm{IV})$ acetylacetonate (Aldrich), also in phenol. ${ }^{[10]}$ Phenol, chloroform, benzene, methanol, isopropanol (Chimmed) and silica gel $60(0.040-0.063 \mathrm{~mm}$, Merck) were used in the work.

VO EP II (2a). Yield: $58 \%$. UV-Vis $\left(\mathrm{CHCl}_{3}\right) \lambda_{\max }(\lg \varepsilon) \mathrm{nm}$ : 408 (5.43), 534 (4.12), $572(4.45) . m / z 543.218\left({ }^{50} \mathrm{~V}\right), 544.262\left({ }^{51} \mathrm{~V}\right)$ $[\mathrm{M}+1]^{+}$. Calculated for $\mathrm{C}_{32} \mathrm{H}_{36} \mathrm{~N}_{4}$ VO: 543.614. HPLC: RT, 10.618 min; complex content: $99.40 \%$. Found, \%: C 70.70, H 6.85, N 10.01. $\mathrm{C}_{32} \mathrm{H}_{36} \mathrm{~N}_{4}$ VO. Calculated, \%: C 70.70, H 6.68, N 10.31.

TiO EP II (2b). Yield $63 \%$. UV-Vis (DMSO) $\lambda_{\text {max }}$ (lge) nm: 404 (5.59), 535 (4.11), 573 (4.37). $m / z$ 539.217, 541.240, 543.257 - Ti isotopes $[\mathrm{M}+1]^{+}$. Calculated for $\mathrm{C}_{32} \mathrm{H}_{36} \mathrm{~N}_{4} \mathrm{TiO}: 540.628 .{ }^{1} \mathrm{H} \mathrm{NMR} \delta_{\mathrm{H}}$ ppm: 10.47 (4H, s, meso-H), $4.22\left(8 \mathrm{H}, \mathrm{q}, \mathrm{CH}_{3}-\mathrm{CH}_{2}-\right), 3.75(12 \mathrm{H}, \mathrm{H}$, $\left.\mathrm{CH}_{3}-\right), 1.97$ (12H, m, $\mathrm{CH}_{3}-\mathrm{CH}_{2}-$ ). HPLC: RT, $9.210 \mathrm{~min}$; complex content: $99.43 \%$. Found, \%: C 71.39, H 6.92, N 9.95. $\mathrm{C}_{32} \mathrm{H}_{36} \mathrm{~N}_{4} \mathrm{TiO}$. Calculated, \%: C 71.09, H 6.71, N 10.36.

\section{Equipment and Reagents}

Electron absorption spectra were recorded with the UV-Vis Helios Alpha Local Control System spectrophotometer (Ter- 
moSpectronic, USA), with the chloroform as a solvent. MALDI mass spectra were obtained with the Bruker Daltonics Inc. mass spectrometer (Germany) equipped with a solid-state UV laser with $\lambda=355 \mathrm{~nm}$ in the reflection mode of positively charged ions registration. An MTP 384 ground steel target (Bruker Daltonics Inc., Germany) was used for mass spectra registration. ${ }^{1} \mathrm{H}$ NMR spectra $(\delta, \mathrm{ppm})$ were obtained with the Bruker DPX-300 device (Germany) at $300 \mathrm{MHz}$ in $\mathrm{CDCl}_{3}$. $\mathrm{HPLC}$ was carried out with the Waters "Breeze" chromatograph with the use of a NovaPack column $(18.4 \mu \mathrm{m}, 4.6 \times 150 \mathrm{~mm})$. Eluent A: $70 \%$ of $\mathrm{CH}_{3} \mathrm{CN}$ in water / $0.1 \%$ TFA; eluent B: ethanol / $0.1 \%$ TFA; B gradient was about $50-95 \%, 0.7 \mathrm{ml} / \mathrm{min}$, detection at $400 \mathrm{~nm}$, registration time equaled $18 \mathrm{~min}$. Kieselgel 60 silica gel (Merck, Germany) was used for column chromatography. X-Ray photoelectronic spectroscopy (XPS) studies were performed with the Kratos AXIS Ultra DLD electronic spectrometer (Kratos Analytical, Great Britain) with a monochromatic X-ray source (A1 K $\alpha, \mathrm{h} v=1486.6$ $\mathrm{eV})$. Fourier IR spectra were recorded by the EQUINOX 55 device (Bruker, Germany) in the middle IR range $\left(4000-700 \mathrm{~cm}^{-1}\right.$, tablet with potassium bromide) and in the far IR range (700-50 $\mathrm{cm}^{-1}$, suspension in petrolatum oil, high-density polyethylene windows). The spectra were processed with the OPUS6.0 program. Geometry optimization and vibrational frequencies calculation were carried out in the Priroda 16 program $^{[11-13]}$ by the density functional method: dft/pbe/L1 in the all-electron scalar relativistic Dyall Modified Dirac approach.

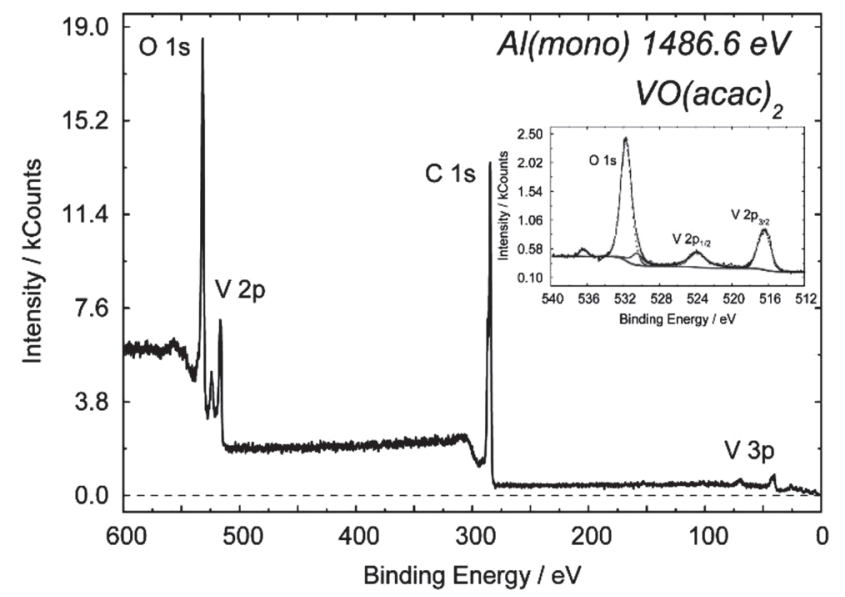

Figure 2. XPS spectra of $\mathrm{VO}(\mathrm{acac})_{2}$ and $\mathrm{TiO}(\mathrm{acac})_{2}$.
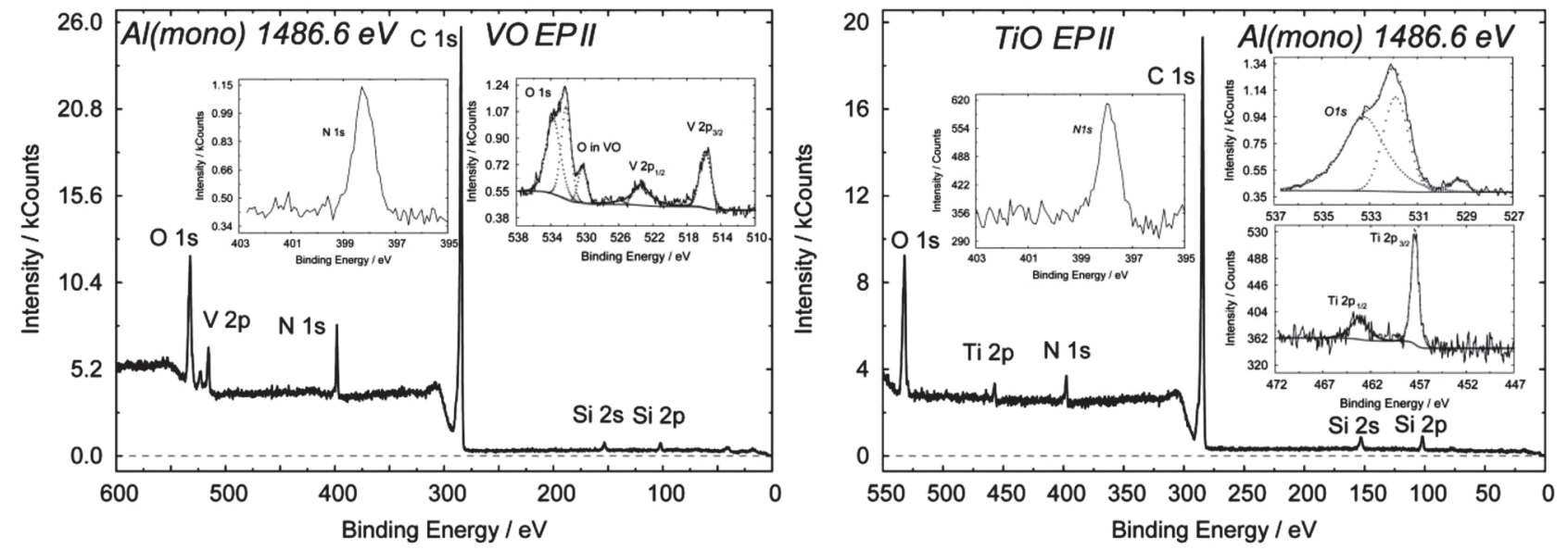

Figure 3. XPS spectra of VO EP II and TiO EP II.

\section{Results and Discussion}

The obtained samples of titanyl and vanadyl complexes with etioporphyrin II were identified with the use of a number of physical methods: electronic spectroscopy, NMR spectroscopy, mass spectrometry and liquid chromatography.

Our studies ${ }^{[1,2]}$ showed that the values of the dipole moments of porphyrins metal complexes were essentially influenced by interactions in the metal-nitrogen core. Bismuth(III) in iodide complexes with porphyrins acts a translator of electron density from the porphyrin cycle atoms to the iodine atom.

X-Ray photoelectronic spectra of titanyl and vanadyl acetylacetonates and the synthesized titanyl and vanadyl complexes with etioporphyrin II are presented in Figures 2 and 3, respectively. Survey XPS spectra contain the lines of all the elements that are a part of the compounds: C1s, N1s, O1s, and also those of transition elements: Ti2 $p_{1 / 2}$, Ti2 $p_{3 / 2}$ and $V 2 p_{1 / 2}, V 2 p_{3 / 2}$ and $V 3 p_{1 / 2}$. The binding energies of the core electrons of nitrogen, carbon, oxygen and transition elements are summarized in Table 1.

As in the case of bismuth iodide complexes, the spectra of the titanyl and vanadyl complex compounds with etiopor-

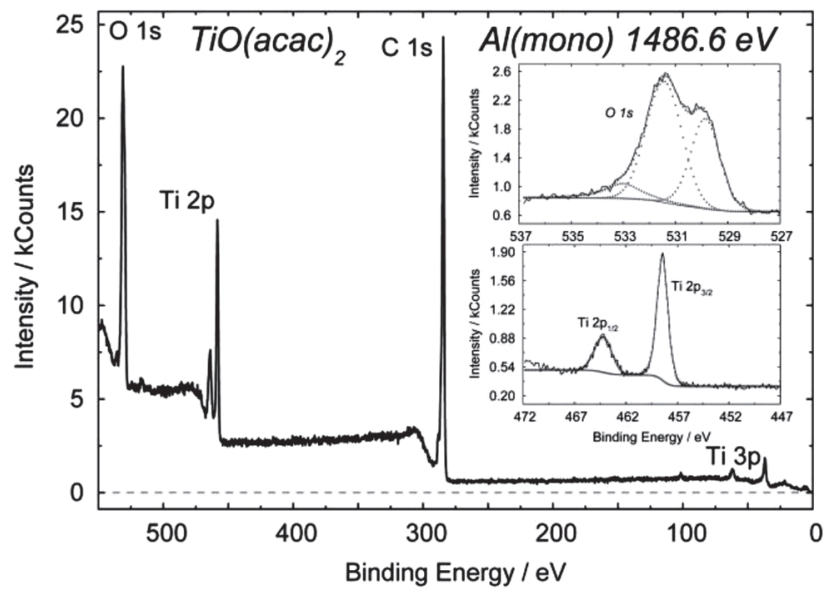


Table 1. The binding energies of the core electrons of vanadyl and titanyl acetylacetonates and porphyrins complexes (eV).

\begin{tabular}{|c|c|c|c|c|c|}
\hline Core levels & $\mathrm{TiO}(\mathrm{acac})_{2}$ & $\mathrm{VO}(\mathrm{acac})_{2}$ & EP II & TiO EP II & VO EP II \\
\hline $\mathrm{O} 1 \mathrm{~s}$ & $\begin{array}{c}531.5 \\
530\end{array}$ & $\begin{array}{l}536.6 \\
531.7\end{array}$ & - & $\begin{array}{c}533.3 \\
532 \\
529.3\end{array}$ & $\begin{array}{c}534 \\
532.3 \\
530.2\end{array}$ \\
\hline $\mathrm{C} 1 \mathrm{~s}$ & $\begin{array}{l}288.5 \\
286.5 \\
284.5\end{array}$ & $\begin{array}{l}286.7 \\
284.4\end{array}$ & $\begin{array}{l}287.5 \\
284.7\end{array}$ & $\begin{array}{l}288.6 \\
286.5 \\
284.7\end{array}$ & 284.8 \\
\hline N1s & - & - & $\begin{array}{l}399.4 \\
397.4\end{array}$ & 397.9 & 398.3 \\
\hline Ti2p & $\begin{array}{l}464.1 \\
458.5\end{array}$ & - & - & $\begin{array}{l}463.4 \\
457.5\end{array}$ & - \\
\hline $\begin{array}{l}\text { Ti3s/ } \\
\text { Ti3pp }\end{array}$ & $\begin{array}{l}61 \\
36\end{array}$ & - & - & - & - \\
\hline $\mathrm{V} 2 \mathrm{p}$ & - & $\begin{array}{c}524 \\
516.6\end{array}$ & - & - & $\begin{array}{l}523.6 \\
515.8\end{array}$ \\
\hline $\begin{array}{l}\text { V3s/ } \\
\text { V3p }\end{array}$ & - & $\begin{array}{l}68.8 \\
40.6\end{array}$ & - & - & 39.1 \\
\hline
\end{tabular}

phyrin II show degenerate bands corresponding to nitrogen $1 \mathrm{~s}$ electrons. The binding energy of the 1s electron of nitrogen atoms in the complexes takes on an average value as compared to etioporphyrin II. However, it is slightly lower than in its complex with bismuth(III) iodide. This indicates that all the nitrogen atoms equally participate in the formation of the bonds with the transition element. As for the binding energy of 1s electrons of carbon, its value for the titanyl complex is significantly higher than for etioporphyrin II, its complexes with bismuth(III) iodide and vanadyl, and it is comparable with the binding energy in titanyl acetylacetonate. On the contrary, the maximum value of the binding energy of oxygen 1s electrons was obtained for the vanadyl etioporphyrin II complex. It should be noted that, while the "apix" O1s oxygen binding energy in the porphyrin vanadyl complex is lower than in acetylacetonate, in the case of titanyl, on the contrary, the O1s binding energy in the porphyrin complex $(533.25 / 532 / 529.3 \mathrm{eV})$ is noticeably higher as compared to the acetylacetonate $(531.47 / 530 \mathrm{eV})$.

According to the literature data ${ }^{[14]}$ the band of titanium $\left(\mathrm{Ti}_{2} \mathrm{p}_{3 / 2} 458.5 \mathrm{eV}\right.$ and $457.5 \mathrm{eV}$ for $\mathrm{TiO}(\mathrm{acac})_{2}$ and $\mathrm{TiO} \mathrm{EP}$ II, respectively) and vanadium (V2 $\mathrm{p}_{3 / 2} 516.6 \mathrm{eV}$ and 515.8 $\mathrm{eV}$ for $\mathrm{VO}(\mathrm{acac})_{2}$ and $\mathrm{VO} \mathrm{EP}$ II, respectively) correspond to the (IV)-valence state of the metal in these compounds. For both titanyl and vanadyl the binding energy of the $p$-electrons of the transition elements in the complexes is slightly lower than in the corresponding acetylacetonates. All this together makes it possible to assume that the polarity of the central core of the complex is higher in the case of titanyl.

The above features of X-ray photoelectronic spectra are in general consistent with the obtained values of vibrational frequencies from the absorption IR spectra (Figure 4). The vibrational frequencies of the bismuth(III) iodide, titanyl and vanadyl etioporphyrin II complexes are summarized in Table 2. The frequencies were assigned on the basis of comparing the experimental data and the performed calculation results.

The assignment of the frequencies of the $\mathrm{M}-\mathrm{O}$ bond valence vibration does not raise any doubt $\left(993 \mathrm{~cm}^{-1}\right.$ for the vanadyl and $961 \mathrm{~cm}^{-1}$ for the titanyl). These vibrations have the aspect of very intense absorption bands in the regions where nonplanar deformation vibrations of the porphyrin cycle $\delta(\mathrm{CH})$ bond also take place.

The frequencies of the valence vibrations of the $\mathrm{M}-\mathrm{O}$ bonds of titanyl acetylacetonate $\left(1024 \mathrm{~cm}^{-1}\right)$ and vanadyl acetylacetonate $\left(998 \mathrm{~cm}^{-1}\right)$ measured by us for comparison
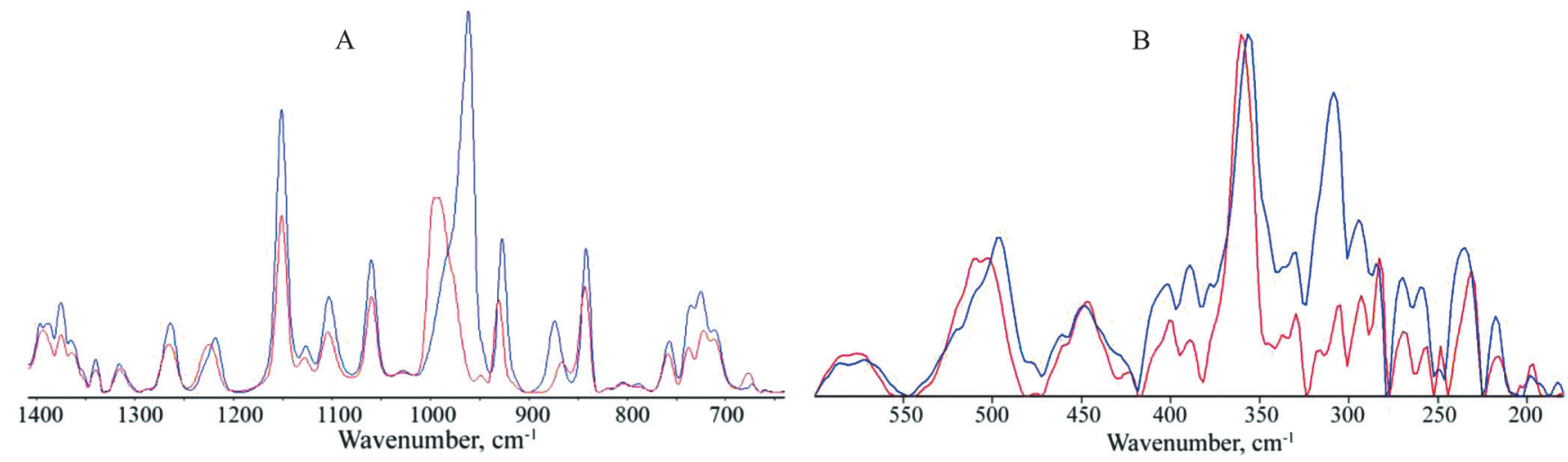

Figure 4. IR spectra of VO (red line) and TiO EP II (blue line) in the middle region (A) and in the far region (B). 
Titanyl and Vanadyl Complexes with Etioporphyrin II

Table 2. The experimental vibrational frequencies of bismuth, vanadyl and titanyl etioporphyrin complexes in the region of porphyrin cycle oscillations $\left(\mathrm{cm}^{-1}\right)$.

\begin{tabular}{|c|c|c|c|c|}
\hline $\begin{array}{l}\text { BiI-EP II } \\
v, \mathrm{~cm}^{-1}\end{array}$ & Assignment & $\begin{array}{l}\text { VO EP II } \\
v, \mathrm{~cm}^{-1}\end{array}$ & $\begin{array}{l}\mathrm{TiO} \text { EP II } \\
v, \mathrm{~cm}^{-1}\end{array}$ & $\begin{array}{l}\text { Assignment } \\
\mathrm{M}=\mathrm{V} / \mathrm{Ti}\end{array}$ \\
\hline 101 & $v(\mathrm{BiI})+v_{\mathrm{as}}(\mathrm{BiN})$ & $\begin{array}{l}217 \\
231\end{array}$ & $\begin{array}{l}218 \\
235\end{array}$ & $v_{\mathrm{s}}(\mathrm{MN})+\delta_{\text {ring }}$ \\
\hline 125 & $\delta(\mathrm{IBiN})+v(\mathrm{BiN})+v(\mathrm{BiI})$ & $\begin{array}{l}257 \\
268\end{array}$ & $\begin{array}{l}260 \\
271\end{array}$ & $\delta(\mathrm{NMO})+\delta_{\text {ring }}$ \\
\hline 156 & $v(\mathrm{BiI})+v(\mathrm{BiN})+\delta(\mathrm{BiNC})$ & $\begin{array}{l}283 \\
293\end{array}$ & $\begin{array}{l}285 \\
294\end{array}$ & $\begin{array}{c}\delta(\mathrm{NMN})+\delta_{\text {ring }}+\delta(\mathrm{MNC}) \\
\delta(\mathrm{NMO})+\delta_{\text {ring }}\end{array}$ \\
\hline 173 & $v(\mathrm{BiN})+\delta(\mathrm{BiNC})+\delta(\mathrm{IBiN})$ & $\begin{array}{l}306 \\
317\end{array}$ & $\begin{array}{c}308 \\
318 \text { shoulder }\end{array}$ & $v_{\mathrm{as}}(\mathrm{MN})+\delta(\mathrm{NMN})+(\mathrm{CNC})$ \\
\hline 228 & $\delta(\mathrm{BiNC})+\delta(\mathrm{IBiN})$ & 330 & 331 & $v(\mathrm{MN})+\delta(\mathrm{MNC})$ \\
\hline 277 & $\delta(\mathrm{BiNC})$ & 360 & 356 & $v_{\mathrm{as}}(\mathrm{MN})+\delta(\mathrm{CNC})$ \\
\hline 301 & $\delta_{\text {ring }}+\delta(\mathrm{NBiN})$ & $\begin{array}{l}389 \\
400\end{array}$ & $\begin{array}{l}390 \\
402 \\
\end{array}$ & $\delta_{\text {ring }}+\delta(\mathrm{NMN})$ \\
\hline $\begin{array}{l}346 \\
373\end{array}$ & $v(\mathrm{BiN})+\delta(\mathrm{BiNC})$ & $\begin{array}{l}423 \\
446 \\
460 \\
\end{array}$ & $\begin{array}{c}425 \text { shoulder } \\
448 \\
462\end{array}$ & $\delta(\mathrm{NMN})+\delta_{\text {ring }}$ \\
\hline $\begin{array}{l}399 \\
418 \\
461 \\
492\end{array}$ & $\delta(\mathrm{CNC})+\delta_{\text {ring }}+\delta(\mathrm{NBiN})$ & $\begin{array}{l}503 \\
510\end{array}$ & $\begin{array}{c}496 \\
511 \text { shoulder }\end{array}$ & $\delta(\mathrm{CNC})+\delta_{\text {ring }}+\delta(\mathrm{NMN})$ \\
\hline 561 & $\delta(\mathrm{CNC})+\delta_{\text {ring }}$ & 579 & $\begin{array}{l}576 \\
586\end{array}$ & $\delta(\mathrm{CNC})+\delta_{\text {ring }}$ \\
\hline $\begin{array}{l}624 \\
662 \\
679\end{array}$ & $\delta(\mathrm{CNC})+\delta_{\text {ring }}$ & $\begin{array}{l}710 \\
720 \\
738\end{array}$ & $\begin{array}{l}711 \\
724 \\
736\end{array}$ & $\delta(\mathrm{CNC})+\delta_{\text {ring }}$ \\
\hline & & 757 & 756 & $\delta(\mathrm{CNC})$ \\
\hline & & 843 & 843 & $\delta_{\text {outpl }}(\mathrm{CCH})$ \\
\hline & & 993 & 961 & $v(\mathrm{MO})$ \\
\hline
\end{tabular}

with the use of their IR spectra are in agreement with the known values. ${ }^{[15]}$ It is obvious that, while the nature of the vanadium-oxygen bond in case of the vanadyl complexes does not undergo considerable changes, the transition from titanium acetylacetonate to its porphyrin complex leads to essential loss of the titanium-oxygen bond strength. The shift of the group of bands related to the valent symmetric and asymmetric $\mathrm{C}-\mathrm{N}$ vibrations confirms the existence of coordination of the $\mathrm{VO}$ and $\mathrm{TiO}$ group to the nitrogen atoms of the porphyrin cycle.

The frequencies of the porphyrin cycle vibrations are not characteristic. They are considerably mixed in shape, which is quite natural for such condensed systems. The frequencies of the vibrations with the participation of metalnitrogen bonds for titanyl $\left(308,356 \mathrm{~cm}^{-1}\right)$ and vanadyl (306, $360 \mathrm{~cm}^{-1}$ ) are practically twice higher than the frequencies of the vibrations with the participation of bismuth-nitrogen bonds. This is understandable, if one takes into account that the atomic mass of bismuth is five times higher than that of titanium and vanadium. Moreover, one can assume some decrease in the metal-nitrogen binding energy for transition elements. This is in agreement with the XPS data. The frequencies of the deformation vibrations of the nitrogen-carbon cycle in the complexes with the participation of transition element atoms are also considerably higher than the frequencies of the corresponding vibrations of the bismuth(III) iodide complex.

In the framework of theoretical investigation, we executed quantum-chemical calculations for the optimization of the geometry of the etioporphyrin II complexes with vanadyl and titanyl cations, a calculation of their vibration spectra, dipole moments, as well as the distribution of charge and spin densities and Mulliken population analysis.

The results of the quantum-chemical calculations are in complete agreement with the above considerations. Thus, for the titanyl complex the Mulliken charges of the titanium and oxygen atoms are equal to 1.41 and -0.43 , respectively. The charges of all four nitrogen atoms are equivalent and equal to -0.50 , and for the carbon atoms bonded with the nitrogen atoms the charges are equal to -0.15 . The residual covalences of $\mathrm{Ti}-\mathrm{N}$ and $\mathrm{Ti}-\mathrm{O}$ bonds are respectively 0.49 and 2.32 . In the case of the vanadyl complex the corresponding values are: 1.25 for $\mathrm{V},-0.38$ for $\mathrm{O},-0.48$ for $\mathrm{N}$, and 0.15 for $\mathrm{C}$. The residual covalences of the $\mathrm{V}-\mathrm{N}$ and $\mathrm{V}-\mathrm{O}$ bonds are 0.52 and 2.33. The calculated dipole moment of the titanyl complex is higher $(2.94 \mathrm{D})$ than in case of vanadyl (2.32 D). 


\section{Conclusion}

Summarizing the obtained results, we can conclude that the "apix" bond of the metals in the vanadyl etioporphyrin II complex has more pronounced covalent nature. In contrast, in the case of titanyl a structure with some redistribution of the electron density to the oxygen atom is implemented. This increases the "apix" Ti-O bond polarity and the dipole moment of the titanyl macrocomplex in general.

Acknowledgements. The work was carried out within the framework of the State task of the Ministry of Education and Science of the Russian Federation (project No 4.9596.2017/8.9). The work was carried out using the equipment of the Collective Use Center of the MIREA - Russian Technological University.

Contribution of authors. Tatyana A. Ageeva - characterization of compounds by physicochemical methods; Denis V. Golubev - quantum-chemical calculations; Anastasiya S. Gorshkova - characterization of compounds by physicochemical methods, article preparation and translation into English; Andrey M. Ionov - XPS analysis; Elena V. Kopylova - registration of NMR spectra; Oskar I. Koifman - results analysis and discussion, article editing; Rais N. Mozhchil XPS registration; Ekaterina P. Rozhkova - HPLC; Valentina D. Rumyantseva - compounds synthesis; Aleksander S. Sigov - results analysis and discussion, article editing; and Valeriy V. Fomichev - results analysis, article writing.

\section{References}

1. Ageeva T.A., Golubev D.V., Gorshkova A.S., Ionov A.M., Koifman O.I., Mozhchil R.N., Rumyantseva V.D., Sigov A.S., Fomichev V.V. Macroheterocycles 2018, 11, 155-161.

2. Golubev D.V., Rumyantseva V.D., Fomichev V.V. Tonkie Khim. Tekhnol. 2017, 12, 26-30 (in Russ.).

3. Gorshkova A.S., Rumyantseva V.D., Mironov A.F. Tonkie Khim. Tekhnol. 2018, 13, 5-20 (in Russ.).

4. Smith K.M., Falk J.E. Porphyrins and Metalloporphyrins. Amsterdam: Elsevier, 1975. 765 p.

5. Erdman J.G., Ramsey V.G., Kalenda N.W., Hanson W.E. J. Am. Chem. Soc. 1956, 78, 5844.

6. Sliznev V.V., Pogonin A.E., Ischenko A.A., Girichev G.V. Macroheterocycles 2014, 13, 60-72 (in Russ.).

7. Fischer H., Orth H. Die Chemie des Pyrrols. II. Leipzig: Akad. Verlagsgesellschaft, 1937. p. 197-199.

8. Dolphin D. The Porphyrins. Structure and Synthesis. Vol. 1 . Part A. London: Academic Press, 1978. p. 390-474.

9. Moeller T. Inorganic Syntheses. Vol. 5. Part 30. New York: McGraw-Hill Book Company, 1957. p. 113-116.

10. Buchler J.W., Eikelmann G., Puppe L., Rohbock K., Schneehage H.H., Weck D. Liebigs Ann. Chem. 1971, 745, 135-151.

11. Laikov D.N. Chem. Phys. Lett. 2005, 416, 116-120.

12. Laikov D.N. Chem. Phys. Lett. 1997, 281, 151-156.

13. Laikov D.N. Russ. Chem. Bull., Int. Ed. 2005, 54, 820-826.

14. Moulder J.F. Handbook of X-Ray Photoelectron Spectroscopy. Perkin-Elmer Corporation Physical Electronics Division, 1992. $261 \mathrm{p}$

15. Nakamoto K. Infrared and Raman Spectra of Inorganic and Coordination Compounds. 6th Edition. Wiley, 2009. $416 \mathrm{p}$. 